\title{
Aetiological significance of chlamydial infections in equine reproductive disorders?
}

\author{
M. M. Wittenbrink \\ Institute of Veterinary Bacteriology, University of Zurich, Switzerland
}

\begin{abstract}
Summary
In the horse, chlamydiae have been incriminated as aetiological agents in a number of extragenital diseases which include pneumonia, conjunctivitis, polyarthritis, and encephalomyelitis. In the mare, genital chlamydial infections are considered as a cause of abortion. Moreover, subclinical genital infections are suggested to cause infertility in the mare as well as in the stallion. However, only few studies have been published concerning involvement of chlamydial agents in those clinical conditions. Chlamydial organisms grown from equine clinical specimens are for the most part unclassified. Thus, epidemiologically as well as aetiologically relevant agent-host-relationships which are well documented for the human genital chlamydiosis and also in parts for the ruminant chlamydiosis, are not well understood for the equine chlamydiosis. The finding that the equine chlamydial strain N16 resembles the significant human pathogen Chlamydia pneumoniae should encourage further studies in the isolation and molecular typing of chlamydiae from healthy and diseased horses.
\end{abstract}

Keywords: Chlamydia, horse, extragenital infection, genital infection, infertility

\section{Genitale Chlamydiose bei Hengst und Stute - Eine reproduktionsmedizinische bedeutsame Infektion?}

Beim Pferd spielen Chlamydien bei einer Reihe von extragenitalen Erkrankungen (Pneumonie, Konjunktivitis, Polyarthritis, Enzephalitis) eine ätiologische Rolle. Bei der Stute werden genitale Chlamydieninfektionen mit Aborten in Zusammenhang gebracht. Darüber hinaus gibt es Hinweise dafür, daß subklinische Infektionen zur Infertilität bei Hengst und Stute führen, jedoch existieren nur wenige Veröffentlichungen, die diese Problematik behandeln. Chlamydiale Organismen, die aus Proben stammen, die bei Routineuntersuchungen beim Pferd gewonnen wurden, sind meist unklassifiziert. Aus diesem Grunde sind epidemiologisch und ätiologisch relevante Aspekte der Erreger-Wirts-Beziehungen, in der humanen Genitalchlamydiose und zum Teil auch bei der Chlamydiose des Rindes gut dokumentiert, beim Pferd noch unklar. Aufgrund der Tatsache, daß der equine Chlamydienstamm N16 Ähnlichkeiten mit dem wichtigen humanpathogenen Erreger Chlamydia pneumoniae aufweist, sollten weitere Studien zur Isolation und molekularen Typisierung von Chlamydien bei gesunden und kranken Pferden durchgeführt werden.

Schlüsselwörter: Chlamydia, Pferd, extragenitale Infektion, Genitalinfektion, Infertilität

\section{Introduction}

Chlamydiosis is a bacterial infection ubiquitously distributed throughout the animal kingdom. The microbial agents of chlamydiosis are highly specialised bacteria that are recognised taxonomically in their own order Chlamydiales due to their unique developmental cycle that involves alternation between two cell types: an infectious form adopted to extracellular survival and an obligatory intracellular form that is metabolically active and replicative. Chlamydiae make up a major phylogenetically distinct group and are proven or suspected pathogens in both humans and animals. Concurrently, the genus Chlamydia (C.) is classified into four species: C. psittaci, C. pecorum, C. pneumoniae, and C. trachomatis, the latter two species being significant human pathogens. The human serovars of $\mathrm{C}$. trachomatis cause amongst others sexually transmitted genitourinary infections and ocular trachoma, the leading cause of preventable blindness world-wide. C. pneumoniae is most commonly known as a significant cause of community-acquired atypical pneumonia in humans. Most recently, this chlamydial species has also been associated with coronary artery disease.
The species C. psittaci includes genetically and antigenically diverse organisms that infect a wide variety of mammalian and avian hosts and that have been implicated in a range of disease conditions in livestock (Storz, 1988). By using genetic-based typing systems, a group of chlamydial strains from ruminants and swine have been found significantly different from other C. psittaci strains and have been, therefore, reclassified as members of the separate species C. pecorum (Anderson et al., 1996; Fukushi and Hirai, 1992, 1993). Both species are well established as genitopathogenic agents in small ruminants, cattle, and swine. In addition, C. psittaci is zoonotic causing predominantly a flulike illness following exposure of humans to psittacine birds (Storz and Kaltenboeck, 1993; Grimes et al., 1996). Sporadically, pregnant women have contracted a gestational chlamydiosis after exposure to ruminant abortogenic C. psittaci (Jorgensen, 1997).

Scientific reports dealing with the equine chlamydiosis are only scarce and little information is available concerning the aetiological significance of chlamydiae in equine infertility. In the following, the prevalence of chlamydial infections in the 
horse and the significance of the agent in equine infertility are reviewed.

\section{Extragenital equine chlamydiosis}

It is evident from a series of serological studies that chlamydial infections are distributed in the horse population in countries world-wide. Serological tests for chlamydial infections in the horse have not been standardised so far and thus data concerning the seropreavalence of equine chlamydiosis from different studies cannot be compared. In former studies chlamydial antibodies have been detected with the aid of the complement fixation test (CFT) but this method has been replaced by the ELISA-technique. In general, the seroprevalence of equine chlamydiosis is considered rather low, ranging from 5 to 18\%. In two studies samples from horses suffering from respiratory disease were compared with samples from healthy controls and in both studies a significantly higher rate of seropositives was found in the group of horses with respiratory disease indicating a possible pathogenic role of chlamydiae in this disease condition (Popovici and Hiastru, 1969; Schmatz et al., 1977). The pathogenic role of chlamydiae in equine respiratory disease was further confirmed by the isolation of the agent from lung tissues of horses suffering from respiratory disease (Moorthy and Spradbrow, 1978; McChesney et al., 1982). On the other hand, isolations of chlamydiae from the upper respiratory tract and from the conjunctiva of apparently healthy horses indicate that inapparent infection is common and can occasionally give rise to disease conditions as pneumonia or conjunctivitis. However, the pathogenic role of chlamydiae in equine respiratory disease has yet to be confirmed by experimental infection with taxonomically characterised chlamydial strains. Hitherto, chlamydial isolates from horses have not been typed with exception of strain N16 which was grown from nasal discharge of a 3year-old thoroughbred horse (Wills et al., 1990). It is of particular interest to note that strain N16 is a member of the species C. pneumoniae. However, DNA sequence analysis of the MOMP gene revealed that strain N16 is quite distinct from the human respiratory isolates and also from a koala conjunctival isolate of C. pneumoniae (Storey et al., 1993). These data suggest that the horse may serve as a reservoir of a distinct branch of $\mathrm{C}$. pneumoniae with a hitherto unknown pathogenic significance even in other clinical conditions. Beside respiratory disease and conjunctivitis chlamydial organisms have been associated with polyarthritis in foals and a so-called hepatoencephalic syndrome (Blanco Loizelier, 1968; McChesney et al., 1974).

\section{Genital equine chlamydiosis}

Chlamydia-induced abortion is generally considered rare in the horse (Popovici and Hiastru, 1968; Blanco Loizelier et al., 1976; Glavits et al., 1988). However, in two further studies evidence was presented for an aetiological role of chlamydiae in equine abortion. Dilbeck et al. (1985) detected chlamydial organisms in 11 of 20 aborted foals (55\%) by means of microscopic examination of histochemically stained impression smears from fetal organs as well as by isolation in cell cultures. Bocklisch et al. (1991) have reported the isolation of chlamydiae from 16 of 59 aborted foals (27.1\%) by initial inoculation of abortion specimens into guinea pigs and subsequent blind passage of guinea pig organs in embryonated hen eggs. The findings of both studies are rather controversial since similar observations have not been made elsewhere. In a retrospective survey on a broad spectrum of specimens from equine abortions, Foster et al. (1997) have failed to detect any indication for the presence of chlamydiae by immunohistochemistry in placental or fetal tissues from 142 aborted foals from Switzerland and by isolation in cell culture, antigen capture ELISA, and PCR of specimens from 49 aborted foals from Northern Germany. Interpretation of the striking discrepancy between these studies is rather difficult. Dilbeck et al. (1985) as well as Bocklisch et al. (1991) have probably investigated epidemic outbreaks of chlamydiosis in single stables, but detailed data of the examined horse populations are missing in both studies. Thus, beside these remarkable episodes of a high rate detection of chlamydiae from aborted foals there is no further indication, e.g. actual well founded case reports, for a serious aetiological significance of chlamydiae in equine abortion.

In humans $\mathrm{C}$. trachomatis infections of the cervix and Fallopian tube are recognised as a significant cause of infertility. Chlamydia-induced endometritis with subsequent infertility has also been described in cattle (Wittenbrink et al., 1993). To further investigate the prevalence and significance of chlamydial infections in the equine uterus, Huelsey (1998) examined amongst other specimens uterine flushings from a total of 81 mares for chlamydial antigen and chlamydial DNA. Chlamydial antigen was detected in 17 specimens $(21.0 \%)$ whereas trials to amplify chlamydial DNA were completely unsuccessful. However, in a sample of ten mares with chlamydial antigen in the uterine flushings, chlamydial inclusions were identified in the luminal and glandular epithelium of uterine biopsies by means of electron microscopy. Further, a marked reduced foaling rate which was analysed in the group of seroconverted mares with uterine chlamydial antigen is suggestive for an association between uterine chlamydial infection and infertility. The findings of Huelsey (1999) are corroborated by the study of Herfen et al. (1999) who detected chlamydial antigen in cervical swabs from 65 of 110 mares $(59,0 \%)$. A significant correlation between the detection of uterine chlamydial infection and clinical signs was not found. However, there was a significant association of genital chlamydial infection in mares that had been covered but were not pregnant. It is quite unclear, whether genital chlamydial infections in the mare are contracted from the respiratory tract which apparently may serve as a reservoir for chlamydiae, or whether chlamydia are introduced into the genital tract with contaminated semen. The ejaculate of stallions can contain chlamydiae and evidence was presented for a correlation 
between the presence of chlamydiae and impaired morphological as well as functional quality of semen Neznik et al., 1996).

In human genital chlamydiosis as well as in genital chlamydiosis of ruminants and swine clinical conditions are associated with certain chlamydial species or subtypes i.e. serotypes. However, chlamydial agents from healthy and diseased horses are for the most part not classified. To further elucidate the relationships of chlamydial agents with certain clinical conditions in the horse, molecular typing methods are indispensable.

\section{Literature}

Anderson, I.E., S.I.F. Baxter, S. Dunbar, A.G. Rae, H.L. Phillips, M.J. Clarkson and A.J. Herring (1996): Analyses of the genomes of chlamydial isolates from ruminants and pigs support the adoption of the new species Chlamydia pecorum. Int. J. Syst. Bacteriol. 46, 245-251

Blanco Loizelier, A. (1968): Las neo-rickettsiosis animales en Espana. Revt. Patron. Biol. Anim. 17, 5-12

Blanco Loizelier, A., M.A. Marcotegui Jaso and I. Delgado Casado (1976): Clamidiosis equina (aborto y poliartritis clamidial en equinos. Anales del Inst. Nacional de Invest. Agr., Hig. y Sanidad Animal 3, 105

Bocklisch, H., C. Ludwig and S. Lange (1991): Chlamydien als Abortursache beim Pferd. Berl. Münch. Tierärztl. Wschr. 104, 119-124

Dilbeck, P.M., J.F. Evermann, S. Kraft and S. Tyler (1985): Equine chlamydial infections: comparative diagnostic aspects with bovine and ovine chlamydiosis. 28th Annual Proc. Amer. Assoc. Vet. Lab. Diagnost., 285-296

Foster, J.L., M.M. Wittenbrink, H.J. Häni, L. Corboz and A. Pospischil (1997): Absence of chlamydia as an aetiological factor in aborting mares. Vet. Rec. 141, 424

Fukushi, H. and K. Hirai (1992): Proposal of Chlamydia pecorum sp. nov. for Chlamydia strains derived from ruminants. Int. J. Syst. Bacteriol. 42, 306-308.

Fukushi, H. and K. Hirai (1993): Chlamydia pecorum - the fourth species of the genus Chlamydia. Microbiol. Immunol. 37, 515-522

Glavits, R., T. Molnar and M. Rady (1988): Chlamydia-induced abortion in a horse. Acta Vet. Hung. 36, 33-36

Grimes, J.E., F. Arizmendi, C.N. Carter and L. Sneed (1996): Diagnostic serologic testing of cage and aviary birds for chlamydiosis and suggested confirmatory testing. J. Vet. Diagn. Invest. 8, 38-44

Herfen, K., C. Jäger and A. Wehrend (1999): Genital chlamydial infections in mares and their clinical significance. Reprod. Dom. Anim. 34,20
Huelsey, A.W. (1998): Chlamydia psittaci als endometriale Infertilitätsursache der Stute. Thesis, Vet. School Hannover, Germany, 1998

Jorgensen, D.M. (1997): Gestational psittacosis in a Montana sheep rancher. Emerg. Infect. Dis. 3, 191-194

McChesney, S.L., V. Becerra and J.J. England (1974): Chlamydial polyarthritis in a foal. J. Amer. Vet. Med. Assoc. 165, 259-261

McChesney, S.L., J.J. England and A.E. McChesney (1982): Chlamydia psittaci induced pneumonia in a horse. Cornell Vet. 72, 92-97

Moorthy, A.R.S. and P.B. Spradbrow (1978): Chlamydia psittaci infection of horses with respiratory disease. Equine Vet. J. 10, 38-42

Popovici, V. and F. Hiastru (1968): Isolation of Bedsonia agents from horses. Rom. Rev. De Zootehnie si Med. Vet. 11, 56-60

Popovici, V. and F. Hiastru (1969): Infections a Bedsonia chez les chevaux. Archiva Vet. 6, 45-51

Schmatz, H.D., S. Schmatz, A. Weber and J. Sailer (1977): Seroepidemiologische Untersuchungen zum Vorkommen von Chlamydien bei Haus- und Wildtieren. Berl. Münch. Tierärztl. Wschr. 90, 74-76

Storey, C., M. Lusher, P. Yates and S. Richmond (1993): Evidence for Chlamydia pneumoniae of non-human origin. J. Gen. Microbiol. 139, 2621-2626

Storz, J. (1988): Overview of animal diseases induced by chlamydial infections. In: Barron A.L. (ed.) Microbiology of Chlamydia. Boca Raton, Fla: CRC Press Inc., 167-192

Storz, J. and B. Kaltenboeck (1993): Diversity of chlamydia-induced diseases, In: Z. Woldehiwet and M. Ristic (ed.) Rickettsial and chlamydial diseases of domestic animals. Pergamon Press, Oxford, England, 363-393

Veznik, Z., D. Svecova, L.Pospisil and I. Diblikova (1996): Detection of Chlamydia spp. In animal and human semen by direct immunofluorescence. Czech., Vet. Med. (Praha) 41, 201-206

Wills, J.M., G. Watson, M. Lusher, T.S. Mair, D. Wood and S.J. Richmond (1990): Characterisation of Chlamydia psittaci isolated from a horse. Vet. Microbiol. 24, 11-19

Wittenbrink, M.M., H.A. Schoon, D. Schoon, R. Mansfeld and W. Bisping (1993): Endometritis in cattle experimentally induced by Chlamydia psittaci. J. Vet. Med., B 40, 437-450

\section{Prof. Dr. M.M. Wittenbrink}

Institute of Veterinary Bacteriology

Faculty of Veterinary Medicine

University of Zurich

Winterthurerstrasse 270

$\mathrm{CH}$-8057 Zurich, Switzerland

Tel: 0041-1-6358601

Fax: 0041-1-6358912 